\title{
Nanofiltration renovation of mineral water
}

\author{
Michał Bodzek $^{1 *}$, Barbara Tomaszewska², Mariola Rajca ${ }^{3}$ \\ ${ }^{1}$ Institute of Environmental Engineering, Polish Academy of Sciences, Poland \\ Silesian University of Technology, Institute of Water and Wastewater Engineering, Poland \\ ${ }^{2} \mathrm{AGH}$ University of Science and Technology, Faculty of Geology, Geophysics and Environmental Protection, Poland \\ Mineral and Energy Economy Research Institute of the Polish Academy of Sciences, Poland \\ ${ }^{3}$ Silesian University of Technology, Institute of Water and Wastewater Engineering, Poland
}

*Corresponding author's e-mail: michal.bodzek@ipis.zabrze.pl

Keywords: mineral water, water renovation, nanofiltration, hydrogeochemical type of water.

\begin{abstract}
There is often a need to improve the taste of mineral water by reducing the sulphate ion content. It was found that for such an effect, nanofiltration (NF) process can be used. In the case, the proposed formula was assumed obtaining a mineral water with reduction of $\mathrm{H}_{2} \mathrm{~S}$ and $\mathrm{SO}_{4}{ }^{2-}$ content through the following processes: stripping - UF/MF or rapid filtration - nanofiltration - mixing with raw water or filtration through calcium bed. The paper shows the results of the tests, with use of mineral waters and nanofiltration. Commercial nanofiltration membranes NF-270 Dow Filmtec and NF-DK GE Infrastructure Water\&Process Technologies were applied. NF was carried out for mixed water from both water intakes ( 1 and 2), recovery of 50\%, at transmembrane pressure of $0.8-1.2 \mathrm{MPa}$ in the dead-end filtration mode. In addition, the permeate obtained in NF was filtered through a column filled with 1.0-3.0 mm limestone rock, in order to improve the composition of mineral water. The tested mineral water is the sulphate-chloride-sodium-calcium-magnesium in nature and contains $991 \mathrm{mg} / \mathrm{L}$ of $\mathrm{SO}_{4}^{2-}$ and $2398 \mathrm{mg} / \mathrm{L} \mathrm{of} \mathrm{TDS}$, while the permeate after NF showed the chloride - sodium hydrogeochemical type (TDS: 780-1470 mg/L, sulfate 10-202.7 mg/L, calcium 23-39.7 mg/L, magnesium 11-28 mg/L). As a result of water treatment in the NF process, high reduction of $\mathrm{SO}_{4}^{2-}$ ions was obtained (79-98.7\%), while the TDS was reduced in 51-64\%. Because the process of NF allows for relatively high reduction of bivalent ions, a significant reduction in calcium ion content (84-88\%) and magnesium (84-89\%) has been also obtained. Monovalent ions were reduced to a lesser extent, i.e. sodium in $46 \%$ and bicarbonates in 39-64.1\%. Despite obtaining the positive effect of the sulphate ions content reduction, the NF process significantly changed the mineralogy composition of water. The permeate filtration (DK-NF membrane) on the $\mathrm{CaCO}_{3}$ deposit led to a correction of the hydrogeochemical type of water from chloridesodium to chloride-bicarbonate-sodium. The concentration of calcium ions was increased by $60.5 \%$ and was $28.2 \mathrm{mg} / \mathrm{L}$, and bicarbonate ions by $7.78 \%$ (increased to $195 \mathrm{mg} / \mathrm{L}$ ). Based on a morphological assessment of the deposits in the SEM image and their chemical composition, the presence of gypsum crystals was detected on the surface of the NF-270 membrane. The deposits formed on the NF-DK membrane were of a completely different character as aggregations of iron and aluminium oxides/hydroxides were found. Such significant mineralogical differences between the secondary deposits crystallising on the surface of the membranes point to the impact of several factors, including membrane characteristics, concentration polarisation, mass transport mechanisms, etc.
\end{abstract}

\section{Introduction}

A new phenomenon of an increase in applications for the production of bottled mineral water, to be consumed in the place of tap water, has recently been noticed both in Poland and in countries of Eastern Europe. A steady year on year growth in their consumption has been observed. They are recommended not only because of their specific taste characteristics and the content of various mineral compounds, but also because of the common conviction, which is prevailing among supporters of bottled waters, that their quality and wholesomeness are very good and generally do not raise as many concerns as tap water. However bottled water has an immensely higher environmental impact than tap water. From the other side, the use of mineral waters for dietary purposes is more and more popular. During the production of mineral waters attention is primarily paid to inorganic ingredients and therefore mainly to the content of mineral compounds.

The concept of mineral water was defined for the first time in 1911 at the International Balneological Congress in Bad Nauheim in Germany, and it was agreed that mineral waters will be considered to be those waters that have at least $1000 \mathrm{mg}$ of minerals per litre. Based on the directive of the European Parliament and of the Council no 2009/54/EC of 18 June 2009 on the exploitation and marketing of natural mineral waters "Natural mineral water can be clearly distinguished from ordinary drinking water: (a) by its nature, which is characterised by its mineral content, trace elements or other constituents and, 
where appropriate, by certain effects; (b) by its original purity, both characteristics having been preserved intact because of the underground origin of such water, which has been protected from all risk of pollution." (Directive 2009). In hydrogeology, the currently generally accepted classification factor for water is also its mineralisation. On this basis groundwater is divided into three groups (Nawrocki 2010):

- mineral waters, in which total mineralisation is more than $1000 \mathrm{mg} / \mathrm{L}$,

- acratopegae with mineralisation within the limits $500-1000 \mathrm{mg} / \mathrm{L}$,

- natural and fresh waters, containing less than $500 \mathrm{mg}$ of mineral salts per litre.

Natural groundwater with desirable biological-chemical properties which is extracted and brought to the surface via an underground borehole must be protected against pollution. In Poland, water which is intended for drinking and sold in packaging as natural water should comply with the requirements of the regulation of the Minister of Health of 31 March 2011 (Regulation 2011). In accordance with that regulation, natural waters are classified into water, mineral waters, spring waters and table waters. Often there is a need to improve the taste of mineral water before bottling by reducing the sulphate ion content. It has been discovered that the use of nanofiltration (NF) is a suitable method for doing this. Nanofiltration is considered to be a most promising technique for the production of high quality water and many examples of its use exist, especially in the drinking water industry. However, papers on mineral water modification using NF process are still not available. Therefore, the application of NF to mineral water treatment can be recognized as a new aspect and worth of investigation. Impurities that are removed include dissolved solids such as inorganic ions, organic carbon, and different kinds of organic compounds. NF techniques are mostly used to soften and remove organic compounds from surface and brackish water. NF membranes are characterised by a high retention of bivalent ions, while the retention of monovalent ions is limited. They are usually polyamide-based, thin-film composite structures, relatively close in chemical structure to reverse osmosis (RO) membranes. Their pore size is $0.5-1.5 \mathrm{~nm}$, ranging between that of ultrafiltration and RO membranes (Burn et al. 2015). Rejection from NF membranes may be attributed to a combination of steric, Donnan, dielectric and transport effects. The transport of neutral solutes is via the steric mechanism (size based exclusion) and has been well established through numerous studies of NF membranes (Burn et al. 2015). The classical Donnan effect describes the equilibria and membrane potential interactions between a charged species and the interface of the charged membrane (Burn et al. 2015). The membrane charge originates from the dissociation of ionisable groups at the membrane surface and from within the membrane pore structure (Ernst et al. 2000). These groups may be acidic or basic in nature or indeed a combination of both depending on the specific materials used during the fabrication process. The dissociation of these surface groups is strongly influenced by the $\mathrm{pH}$ of the contacting solution and when the membrane surface chemistry is amphoteric in nature, the membrane may exhibit an isoelectric point at a specific $\mathrm{pH}$ (Burn et al. 2015). In addition to the ionisable surface groups, NF membranes have a weak ion-exchange capacity and in some cases ions from the contacting solution may adsorb onto the membrane surface causing a slight modification to the membrane charge (Schaep and Vandecasteele 2001).

The aim of the study was to modify the physicochemical properties of mineral waters intended for bottling. The research work proceeded in the direction of determining the possibility of reducing the sulphate ion content in mineral waters to the extent necessary to improve them in terms of water taste. The assumption is that the nanofiltration process (NF) can be used to reduce the salt content and obtain a product, and that this process could contribute to an reduction in water TDS, including, first of all, the bivalent ions: $\mathrm{Ca}^{2+}, \mathrm{Mg}^{2+}, \mathrm{Ba}^{2+}, \mathrm{Sr}^{2+}$, $\mathrm{Mn}^{2+}$ and $\mathrm{SO}_{4}^{2-}$ (by approximately $80 \%$ ). An important step in the proposal to identify processes to modify the water's organoleptic properties is the removal of hydrogen sulphide, because this has an influence on creating an unacceptable smell in the water. It was assumed that the procedure used would produce mineral water with reduced content of $\mathrm{H}_{2} \mathrm{~S}$ and $\mathrm{SO}_{4}^{2-}$ ions. The aim of this procedure was to obtain water with greatly altered taste values. A diagram of the proposed procedure is shown in Fig. 1.

The presented procedure is the proposition for industrial applications. The important first step to modify the water's organoleptic properties is the removal of hydrogen sulphide, because this has an influence on creating an unacceptable smell in the water. Next elements of water treatment procedure include: water pre-treatment in Ultra/Microfiltration, next - Nanofiltration as the main process, and final process as the mixing of permeates after UF/MF and NF processes, to obtain adequate to the needs water composition.

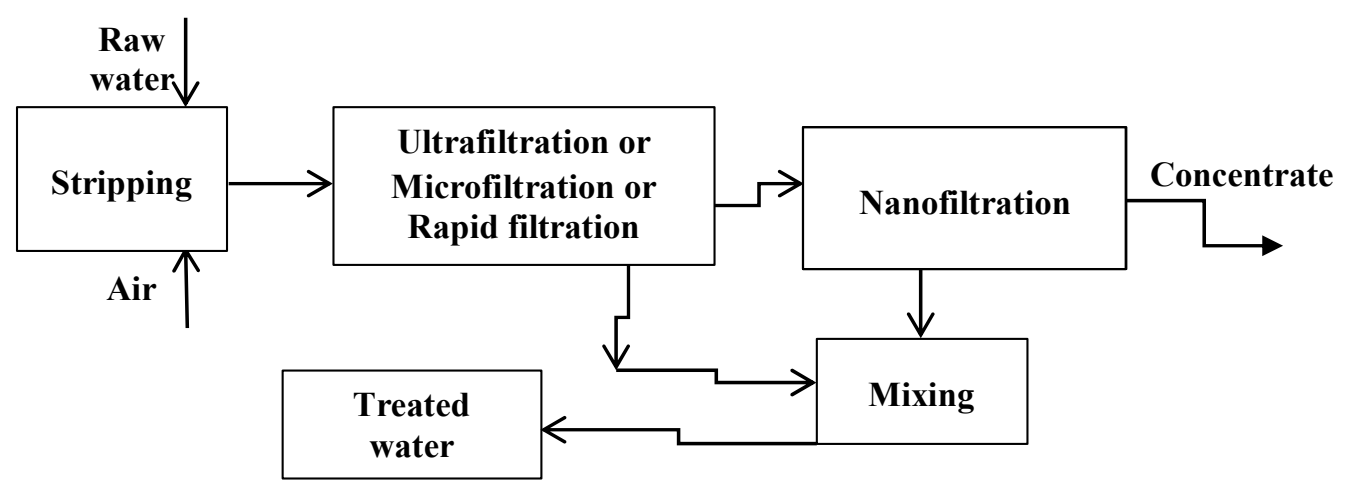

Fig. 1. Proposed scheme for the treatment of the mineral water analysed 


\section{Materials and methods}

The study involved two deep water intakes having a TDS of about $2.8 \mathrm{~g} / \mathrm{L}$ and $2 \mathrm{~g} / \mathrm{L}$. Due to the similar degree of TDS, the experiments were conducted using a mixture of water from both intakes, prepared in an equal volume ratio. Before carrying out a test, the water was degassed (aerated) to remove hydrogen sulphide and iron precipitation. The temperature of the waters tested was $20^{\circ} \mathrm{C}$.

The membrane process was conducted in the dead-end filtration mode. A pressure device was applied in order to do this which consisted of a steel cell (volume: $400 \mathrm{~cm}^{3}$ ) and magnetic stirrer (Fig. 2). NF was carried out with a water recovery of $50 \%$ at a transmembrane pressure of $0.8-1.2 \mathrm{MPa}$. The active area of the membrane was $35.2538 .5 \mathrm{~cm}^{2}$. NF-270 Dow Filmtec and NF-DK GE Infrastructure Water \& Process Technologies nanofiltration membranes were applied. The characteristics of the membranes are shown in Table 1. Both membranes are characterised by a negative surface charge in a wide range of $\mathrm{pH}$ (Nghiem and Hawkes 2007, Al-Amoudi et al. 2007).

New membranes were conditioned by filtration of deionised water to stabilise the permeate flux, and this was then followed by membrane filtration to obtain $50 \%$ volume of feed, the volume of the permeate flux being measured at this time.

The permeate obtained from NF was filtered through a column filled with limestone rock in order to improve the composition of the mineral water. A $1.0-3.0 \mathrm{~mm}$ aggregate fraction was used in the tests. Filtration was conducted in a column filled with a quantity of approx. $200 \mathrm{~g}$ of aggregate deposit through which $50 \mathrm{~mL}$ of permeate was passed.

In order to produce an assessment of the quality of the raw water, permeate, and concentrate after the NF process, and the water saturated with calcium carbonate, an analysis of the content of the basic mineral components was carried out. Inorganic components were measured at an accredited laboratory (PCA-AB 1050) using ICP-OES and ICP-MS methods and $\mathrm{pH}$ was measured immediately after sampling the water using the electrometric method. Chloride ion concentration and alkalinity were determined by titration following accredited testing procedures. Before the determination, samples were prepared by means of filtration through a membrane filter of $0.45 \mu \mathrm{m}$ and acidified using $1 \mathrm{~mL}$ ultrapure nitric acid for each $100 \mathrm{~mL}$ of samples.

The mineral composition of sediments on the membrane surface was determined via the powder X-ray diffraction (XRD) method (Tomaszewska and Bodzek 2013a). Also the membrane morphology of the membranes used was determined using a scanning electron microscope (SEM).

\section{Results and discussion}

\section{Physicochemical characteristics of the water investigated}

The mineral water resource exists in fractured marls of the Lower Baden and sandy Paleogenic formations which fill

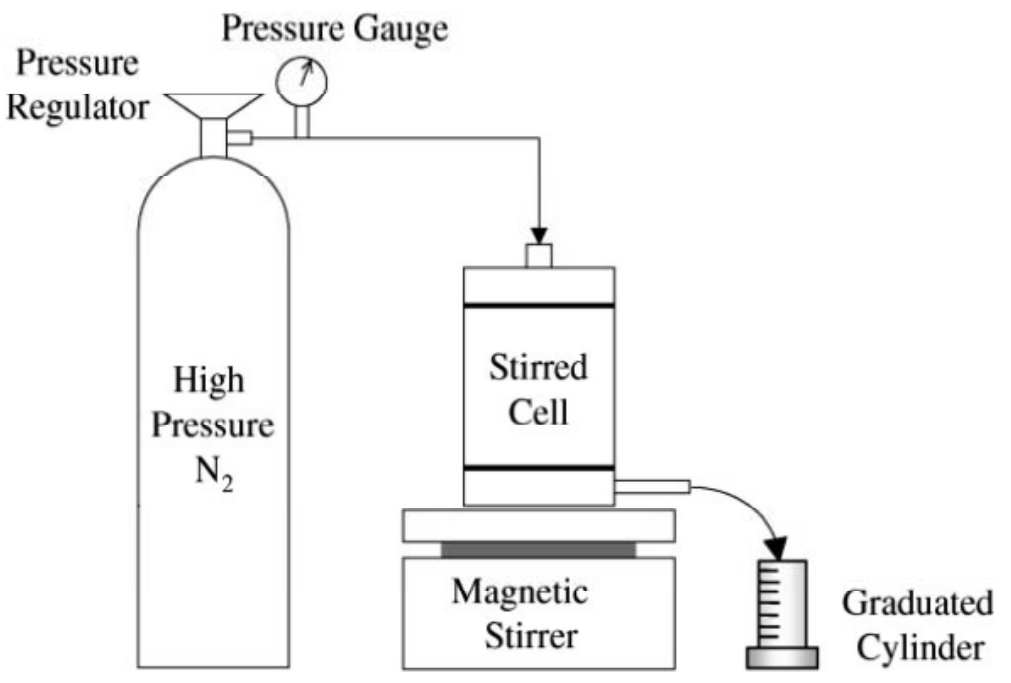

Fig. 2. Diagram of the system for carrying out membrane filtration in dead-end mode

Table 1. Membrane characteristics (manufacturers' data)

\begin{tabular}{|c|c|c|}
\hline Membrane symbol & NF-DK & NF-270 \\
\hline Membrane material & polyamide & polyamide thin-film composite \\
\hline Mol. weight cut-off (Dalton) & $150-300$ & $200-400$ \\
\hline \multirow{2}{*}{ Transmembrane pressure, MPa } & recommended 2.7 & - \\
\cline { 2 - 3 } & maximum 4.0 & 4.1 \\
\hline $\mathrm{pH}$ range & $3-9$ & $2-11$ \\
\hline Maximum temperature, ${ }^{\circ} \mathrm{C}$ & 50 & 45 \\
\hline Retention coefficient & $98 \% \mathrm{MgSO}_{4}$ & $99.2 \% \mathrm{MgSO}_{4}$ \\
\hline
\end{tabular}


cavities and karstic forms in the Jurassic limestones. The depth of their occurrence is from 26.0 to 44.7 metres below ground level. They are fracture-karst and pore waters of an artesian type. The extraction of mineral waters is mainly performed using two deep intakes. The chemical composition of the mineral waters is shown in Table 2.

The physicochemical properties of the waters from both intakes, expressed by the Kurłow formula (specific component in $\mathrm{mg} / \mathrm{L}$, mineralisation $(\mathrm{M})$ in $\mathrm{g} / \mathrm{L}$, main ions in $\%$ mval) are as follows:

Water intake 1: $\quad \mathrm{H}_{2} \mathrm{~S}^{4,2} \mathrm{M}^{2,2} \frac{\mathrm{SO}_{4}^{44} \mathrm{Cl}^{36} \mathrm{HCO}_{3}^{19}}{\mathrm{Na}^{62} \mathrm{Ca}^{19} \mathrm{Mg}^{17} \mathrm{~K}^{1}}$

Water intake 2: $\quad \mathrm{H}_{2} \mathrm{~S}^{8,4} \mathrm{M}^{2,9} \frac{\mathrm{SO}_{4}^{58} \mathrm{Cl}^{29} \mathrm{HCO}_{3}^{13}}{\mathrm{Na}^{46} \mathrm{Ca}^{26} \mathrm{Mg}^{26} \mathrm{~K}^{1}}$

In hydrogeochemical terms the water from intake 1 is considered as sulphate-chloride bicarbonate-sodium-calcium sulphide in character. It is multi-ion water with increased major ion content: $\mathrm{SO}_{4}, \mathrm{Cl}, \mathrm{HCO}_{3}, \mathrm{Na}$ and $\mathrm{Ca}$. The water from intake 2, in hydrogeochemical terms, is considered as sulphate-chloride-sodium-calcium-magnesium-sulphide. Like the water from intake 1, it is multi-ion water with increased major ion content: $\mathrm{SO}_{4}, \mathrm{Cl}, \mathrm{Na}, \mathrm{Ca}$ and $\mathrm{Mg}$. Next to the so called macro components, there are significant concentrations of iodides in the water from both intakes: $0.51 \mathrm{mg} / \mathrm{L}$ in water intake 1 and $0.018 \mathrm{mg} / \mathrm{L}$ in water intake 2 .

\section{Nanofiltration of mineral water}

Figs. 3 and 4 show the change in permeate flux with time, and Tables 3 and 4 present the results of physicochemical parameters during nanofiltration of the mixed mineral water from both intakes at a volume ratio 1:1 for both the membranes applied.

Studies have shown a loss of membrane efficiency with time during the NF, especially in the case of NF-270 membrane process which indicates the efficiency of, fouling and/or scaling phenomena.

It was found that there was a low retention of chlorides, a very high retention of sulphates, and a significant retention of bivalent and hardness cations. The small retention of boron was related to the fact that the $\mathrm{pH}$ of the water does not exceed the value of 7 . Higher retention rate for boron, at a level exceeding $98 \%$, is possible in water with a $\mathrm{pH}$ value of at least 10 (Tomaszewska and Bodzek 2013b). A sharp decrease in retention was also found with increasing pressure.

The hydrogeochemical character of the water tested, i.e. a mixture from intakes 1 and 2 at a volume ratio of $1: 1$, was sulphate-chloride-sodium-magnesium-calcium. The mixture contained $991 \mathrm{mg} / \mathrm{L}$ of sulphate ions and the values for the total content of dissolved substances (TDS) were $2398 \mathrm{mg} / \mathrm{L}$. After

Table 2. Average concentration of components of raw mineral waters

\begin{tabular}{|c|c|c|c|}
\hline Parameter & Unit & Water intake 1 & Water intake 2 \\
\hline $\mathrm{pH}$ & - & 7.65 & 7.42 \\
\hline Conductivity & $\mathrm{mS} / \mathrm{cm}$ & 2.63 & 3.15 \\
\hline Total hardness & $\mathrm{mg} \mathrm{CaCO}_{3} / \mathrm{L}$ & 432.1 & 756.9 \\
\hline Carbonate hardness & $\mathrm{mg} \mathrm{CaCO}_{3} / \mathrm{L}$ & 349.1 & 317.5 \\
\hline $\mathrm{H}_{2} \mathrm{~S}$ & $\mathrm{mg} / \mathrm{L}$ & 1.54 & 2.07 \\
\hline TDS & $\mathrm{mg} / \mathrm{L}$ & 1920 & 2284 \\
\hline $\mathrm{Na}^{+}$ & $\mathrm{mg} / \mathrm{L}$ & 434.8 & 428.4 \\
\hline $\mathrm{K}^{+}$ & $\mathrm{mg} / \mathrm{L}$ & 16.1 & 15.8 \\
\hline $\mathrm{Ca}^{2+}$ & $\mathrm{mg} / \mathrm{L}$ & 84.5 & 147.4 \\
\hline $\mathrm{Mg}^{2+}$ & $\mathrm{mg} / \mathrm{L}$ & 53.7 & 94.1 \\
\hline $\mathrm{Ba}^{2+}$ & $\mathrm{mg} / \mathrm{L}$ & 0.013 & 0.05 \\
\hline $\mathrm{Sr}^{2+}$ & $\mathrm{mg} / \mathrm{L}$ & 2.06 & 3.2 \\
\hline $\mathrm{Fe}^{2+}$ & $\mathrm{mg} / \mathrm{L}$ & 0.15 & 0.25 \\
\hline $\mathrm{Mn}^{2+}$ & $\mathrm{mg} / \mathrm{L}$ & 0.02 & 0.011 \\
\hline $\mathrm{As}^{3+}$ & $\mathrm{mg} / \mathrm{L}$ & 0.045 & 0.004 \\
\hline $\mathrm{F}^{-}$ & $\mathrm{mg} / \mathrm{L}$ & 0.947 & 1.00 \\
\hline $\mathrm{Cl}^{-}$ & $\mathrm{mg} / \mathrm{L}$ & 366 & 388.9 \\
\hline $\mathrm{Br}^{-}$ & $\mathrm{mg} / \mathrm{L}$ & 0.8 & 0.42 \\
\hline I & $\mathrm{mg} / \mathrm{L}$ & 0.51 & 0.018 \\
\hline $\mathrm{SO}_{4}{ }^{2-}$ & $\mathrm{mg} / \mathrm{L}$ & 533.9 & 821.9 \\
\hline $\mathrm{HCO}_{3}^{-}$ & $\mathrm{mg} / \mathrm{L}$ & 426.6 & 387.3 \\
\hline $\mathrm{H}_{2} \mathrm{SiO}_{3}$ & $\mathrm{mg} / \mathrm{L}$ & 12.7 & 11.64 \\
\hline $\mathrm{HBO}_{2}^{-}$ & $\mathrm{mg} / \mathrm{L}$ & 4.65 & 4.24 \\
\hline
\end{tabular}




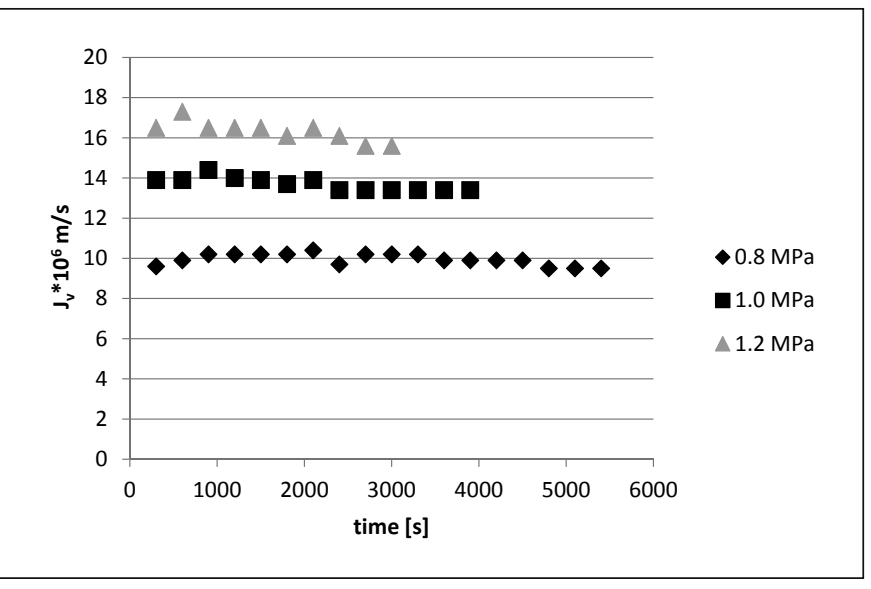

Fig. 3. Changes of permeate flux during nanofiltration of mineral water using the NF-DK membrane.

Explanation: Jv - permeate flux

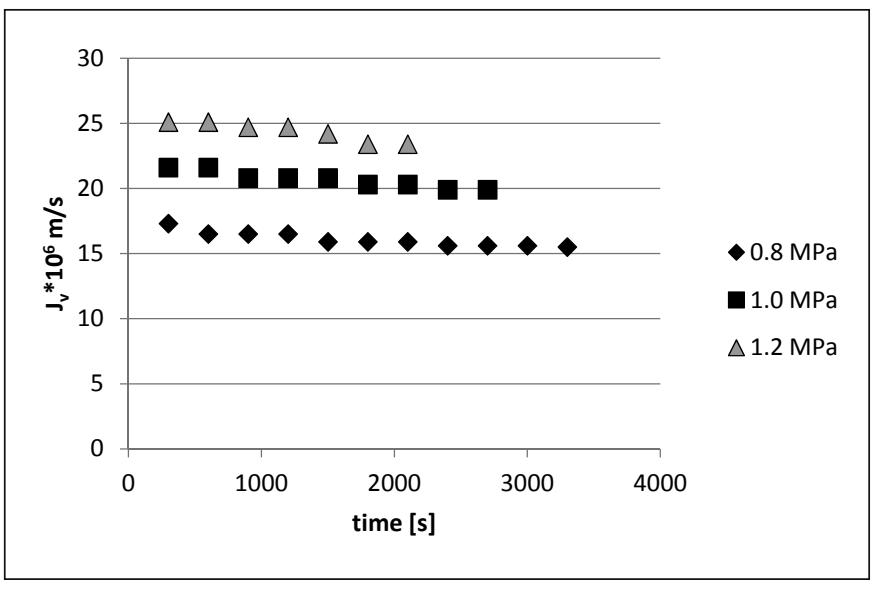

Fig. 4. Changes of permeate flux during nanofiltration of mineral water using the NF-270 membrane.

Explanation: Jv - permeate flux

Table 3. Results of treating mineral water using a NF-270 Dow Filmtec nanofiltration membrane $(\Delta \mathrm{P}$ - transmembrane pressure, $\mathrm{R}$ - retention coefficient)

\begin{tabular}{|c|c|c|c|c|c|c|c|c|}
\hline $\begin{array}{l}\frac{n}{0} \\
\frac{D}{ \pm} \\
\frac{E}{\pi} \\
\frac{\pi}{\pi} \\
0 \\
0\end{array}$ & 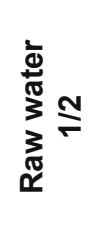 & 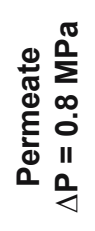 & $\frac{\mathfrak{0}}{\alpha}$ & 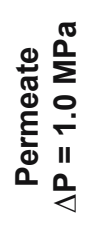 & $\frac{\mathfrak{0}}{\alpha}$ & 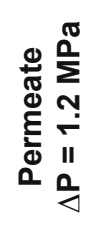 & $\frac{\sqrt{0}}{\alpha}$ & 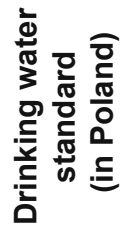 \\
\hline 1) TDS & 2398 & 780.4 & 64.1 & 827.5 & 62.0 & 848.0 & 61.0 & $2500^{3)}$ \\
\hline 2) Total hardness & 829.6 & 117 & 84.3 & 123.9 & 83.4 & 125.0 & 83.3 & $60-500$ \\
\hline 1) $\mathrm{Na}^{+}$ & 463.7 & 243.5 & 46.6 & 257.1 & 43.6 & 263.8 & 42.2 & 200 \\
\hline 1) $\mathrm{Ca}^{2+}$ & 151.7 & 22.7 & 84.4 & 24.7 & 83.0 & 25.0 & 82.8 & - \\
\hline 1) $\mathrm{Mg}^{2+}$ & 109.6 & 14.87 & 84.2 & 15.2 & 83.8 & 15.2 & 83.7 & $30-125$ \\
\hline 1) $\mathrm{Cl}^{-}$ & 455.5 & 376.2 & 18.1 & 401.5 & 12.5 & 400.1 & 12.85 & 250 \\
\hline 1) $\mathrm{Br}$ & 0.797 & 0.467 & 6.62 & 0.482 & 3.64 & 0.50 & 0.00 & 0.01 \\
\hline 1) $\mathrm{SO}_{4}{ }^{2-}$ & 990.7 & 10.4 & 98.7 & 11.5 & 98.6 & 14.1 & 98.2 & 250 \\
\hline 1) $\mathrm{HCO}_{3}^{-}$ & 368.0 & 186.8 & 49.4 & 191.0 & 48.3 & 213.7 & 42.15 & - \\
\hline 1) $\mathrm{CO}_{3}^{2-}$ & 0.50 & 0.50 & 0.00 & 0.50 & 0.00 & 0.50 & 0.00 & - \\
\hline 1) $\mathrm{HBO}_{2}$ & 7.65 & 3.65 & 9.64 & 3.97 & 1.68 & 4.125 & - & $1^{4)}$ \\
\hline
\end{tabular}

1) in $\mathrm{mg} / \mathrm{L} ;{ }^{2)}$ in $\mathrm{mg} \mathrm{CaCO} /\left(\mathrm{L} ;{ }^{3)}\right.$ as electrical conductivity in $\mathrm{mS} / \mathrm{cm}$; ${ }^{4)}$ as boron ion in $\mathrm{mg} / \mathrm{L}$

NF, the permeate changed its hydrogeochemical type to chloride-sodium (TDS: 780-1470 mg/L, sulfate 10-202.7 mg/L, calcium 23-39.7 mg/L, magnesium 11-28 mg/L).

Treatment of the water in a NF process using an NF-270 membrane resulted in a large reduction in the concentration of $\mathrm{SO}_{4}^{2-}$ ions (circa 98\%), while the TDS was reduced by $61-64 \%$. Because the process of NF allows for a relatively large reduction in the concentration of bivalent ions, a significant reduction in the calcium (83-84\%) and magnesium (84\%) ion content was also obtained. Monovalent ions were reduced to a lesser extent, i.e. sodium by $42-46 \%$ and bicarbonates by $42-49 \%$. In the case of the NF-DK membrane, a large, $96.3 \%$, reduction in the $\mathrm{SO}_{4}{ }^{2-}$ ion content was also achieved. The TDS of the water was reduced by approx. $50 \%$. Because the nanofiltration process allows for a relatively large reduction in the concentration of bivalent ions, a significant reduction in the concentration of the calcium $(88.4 \%)$ and magnesium $(89.4 \%)$ ions were also achieved. Monovalent ions, i.e. sodium $(46.6 \%)$ and carbohydrates $(50.8 \%)$, were retained to a minor extent.

The composition of the waters (before and after filtration) has been matched with national (Polish) drinking water guidelines (Table 3 and 4). It is correct that these are in fact not valid, but they can nevertheless be taken as a reference. It has been shown that sulfates are limited in Polish regulations, which is a motivation for this treatment. Some other parameters would not fulfill the criteria, which is not necessarily a problem (for bottled mineral water), but it should be clear for potential customers.

In the concentrate, which is the liquid created by the separation of ions in the nanofiltration process, a significant increase was noted in the content of most of the ingredients (Tomaszewska et al. 2014). Water of a sulphate-chloride- 
-sodium-magnesium-calcium hydrogeochemical type was obtained with a TDS of approximately $3700 \mathrm{mg} / \mathrm{L}$ for the NF-270 membrane and approximately $4300 \mathrm{mg} / \mathrm{L}$ for the NF-DK membrane. The concentration of sulphates was approximately $1600 \mathrm{mg} / \mathrm{L}$ (NF-270) and 1700-1889 mg/L (NF-DK), calcium 260-280 mg/L (for both membranes) and magnesium 168-170 mg/L (NF-270) and 186-197 (NF-DK) mg/L.

\section{Correction of the mineral composition of the nanofiltration permeate}

The treatment of water after desalination depends on its further use. The raw permeate obtained from NF/RO frequently does not meet the standards for mineral/drinking water established in Poland and in the European Union (Fritzmann et al. 2007). The final treatment of water after RO is a very important part of the desalination facility.
Despite obtaining a beneficial effect in reducing the concentration of sulphate ions, the NF process, however, significantly changed the mineral composition of the water (Table 3 and 4). This was the reason for filtering the permeate (from the DK-NF membrane) through a $\mathrm{CaCO}_{3}$ bed in order to correct the hydrogeochemical type of water from chloride-sodium to chloride-bicarbonate-sodium. The process was run according to the reaction:

$$
\mathrm{CO}_{2}+\mathrm{CaCO}_{3}+\mathrm{H}_{2} \mathrm{O}=\mathrm{Ca}\left(\mathrm{HCO}_{3}\right)_{2}
$$

The concentration of calcium ions was increased by $60.5 \%$ at a pressure of $0.8 \mathrm{MPa}$ and was $28.2 \mathrm{mg} / \mathrm{L}$, $44.8 \mathrm{mg} / \mathrm{L}$ at $1.0 \mathrm{MPa}$ and 44.2 at $1.2 \mathrm{MPa}$, while bicarbonate ions increased by $7-8 \%$ (to $180-195 \mathrm{mg} / \mathrm{L}$ ), depending on pressure (Table 5).

Table 4. Results of treating mineral water using an NF-DK GE nanofiltration membrane ( $\Delta \mathrm{P}$ - transmembrane pressure, $\mathrm{R}$ - retention coefficient)

\begin{tabular}{|c|c|c|c|c|c|c|c|c|}
\hline $\begin{array}{l}\frac{\infty}{d} \\
\frac{D}{0} \\
\frac{c}{\sigma} \\
\frac{\sigma}{\sigma} \\
0\end{array}$ & 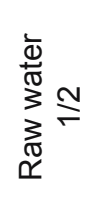 & 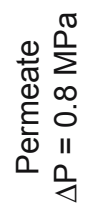 & $\frac{\check{2}}{\alpha}$ & 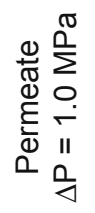 & $\frac{\sqrt{2}}{\not{a}}$ & 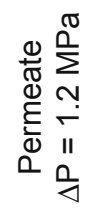 & $\frac{\sqrt{\circ}}{\alpha}$ & 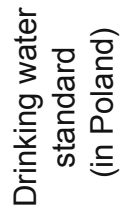 \\
\hline 1) TDS & 2398 & 1176 & 51.0 & 1470 & 38.7 & 1415 & 41.0 & $2500^{3)}$ \\
\hline 2) Total hardness & 829.6 & 91.62 & 88.9 & 186.1 & 77.6 & 214.3 & 74.2 & $60-500$ \\
\hline 1) $\mathrm{Na}^{+}$ & 463.7 & 247.5 & 46.6 & 281.8 & 39.2 & 294.1 & 36.6 & 200 \\
\hline 1) $\mathrm{Ca}^{2+}$ & 151.7 & 17.59 & 88.4 & 34.84 & 77.0 & 39.73 & 73.8 & - \\
\hline 1) $\mathrm{Mg}^{2+}$ & 109.6 & 11.60 & 89.4 & 24.10 & 78.0 & 28.0 & 74.5 & $30-125$ \\
\hline 1) $\mathrm{Cl}^{-}$ & 455.5 & 549.5 & - & 599.1 & - & 542.4 & - & 250 \\
\hline 1) $\mathrm{Br}$ & 0.797 & 1.61 & - & 2.16 & 171.0 & 1.93 & - & 0.01 \\
\hline 1) $\mathrm{SO}_{4}^{2-}$ & 990.7 & 36.44 & 96.3 & 162.1 & 83.6 & 202.7 & 79.5 & 250 \\
\hline 1) $\mathrm{HCO}_{3}^{-}$ & 368.0 & 181.2 & 50.8 & 201.0 & 45.4 & 206.6 & 43.9 & - \\
\hline 1) $\mathrm{CO}_{3}^{2-}$ & 0.50 & 0.50 & 0.00 & 0.50 & 0.00 & 0.50 & 0.00 & - \\
\hline 1) $\mathrm{HBO}_{2}$ & 7.65 & 7.82 & - & 9.21 & - & 9.46 & - & 14) \\
\hline
\end{tabular}

${ }^{1)}$ in $\mathrm{mg} / \mathrm{L} ;{ }^{2)}$ in $\mathrm{mg} \mathrm{CaCO}\left({ }_{3} / \mathrm{L} ;{ }^{3)}\right.$ as electrical conductivity in $\mathrm{mS} / \mathrm{cm} ;{ }^{4)}$ as boron ion in $\mathrm{mg} / \mathrm{L}$

Table 5. Results of a remineralisation of the NF permeate obtained using the NF-DK GE membrane

\begin{tabular}{|c|c|c|c|c|c|c|c|}
\hline \multirow[b]{2}{*}{ Parameters } & \multirow{2}{*}{$\begin{array}{c}\text { Raw water } \\
1 / 2\end{array}$} & \multicolumn{2}{|c|}{$\Delta \mathrm{P}=0.8 \mathrm{MPa}$} & \multicolumn{2}{|c|}{$\Delta \mathrm{P}=1.0 \mathrm{MPa}$} & \multicolumn{2}{|c|}{$\Delta \mathrm{P}=1.2 \mathrm{MPa}$} \\
\hline & & Permeate & $\begin{array}{c}\text { After } \mathrm{CaCO}_{3} \\
\text { filtration }\end{array}$ & Permeate & $\begin{array}{c}\text { After } \mathrm{CaCO}_{3} \\
\text { filtration }\end{array}$ & Permeate & $\begin{array}{c}\text { After } \mathrm{CaCO}_{3} \\
\text { filtration }\end{array}$ \\
\hline 1) TDS & 2398 & 1176 & 995 & 1470 & 1071 & 1415 & 1075 \\
\hline 2) Total hardness & 829.6 & 91.6 & 118 & 186 & 202 & 214 & 211 \\
\hline 1) $\mathrm{Na}^{+}$ & 463.7 & 247.5 & 277 & 282 & 291 & 294 & 287 \\
\hline 1) $\mathrm{Ca}^{2+}$ & 151.7 & 17.6 & 28.2 & 34.8 & 44.8 & 39.7 & 44.2 \\
\hline 1) $\mathrm{Mg}^{2+}$ & 109.6 & 11.6 & 11,6 & 24.1 & 22.1 & 28.0 & 24.4 \\
\hline 1) $\mathrm{Cl}^{-}$ & 455.5 & 549.5 & 402 & 599 & 408 & 542 & 399 \\
\hline 1) $\mathrm{SO}_{4}{ }^{2-}$ & 990.7 & 36.4 & 45.4 & 162 & 177 & 203 & 185 \\
\hline 1) $\mathrm{HCO}_{3}^{-}$ & 368.0 & 181 & 195 & 201 & 186 & 207 & 190 \\
\hline
\end{tabular}

1) in $\mathrm{mg} / \mathrm{L} ;{ }^{2)}$ in $\mathrm{mg} \mathrm{CaCO}_{3} / \mathrm{L}$ 

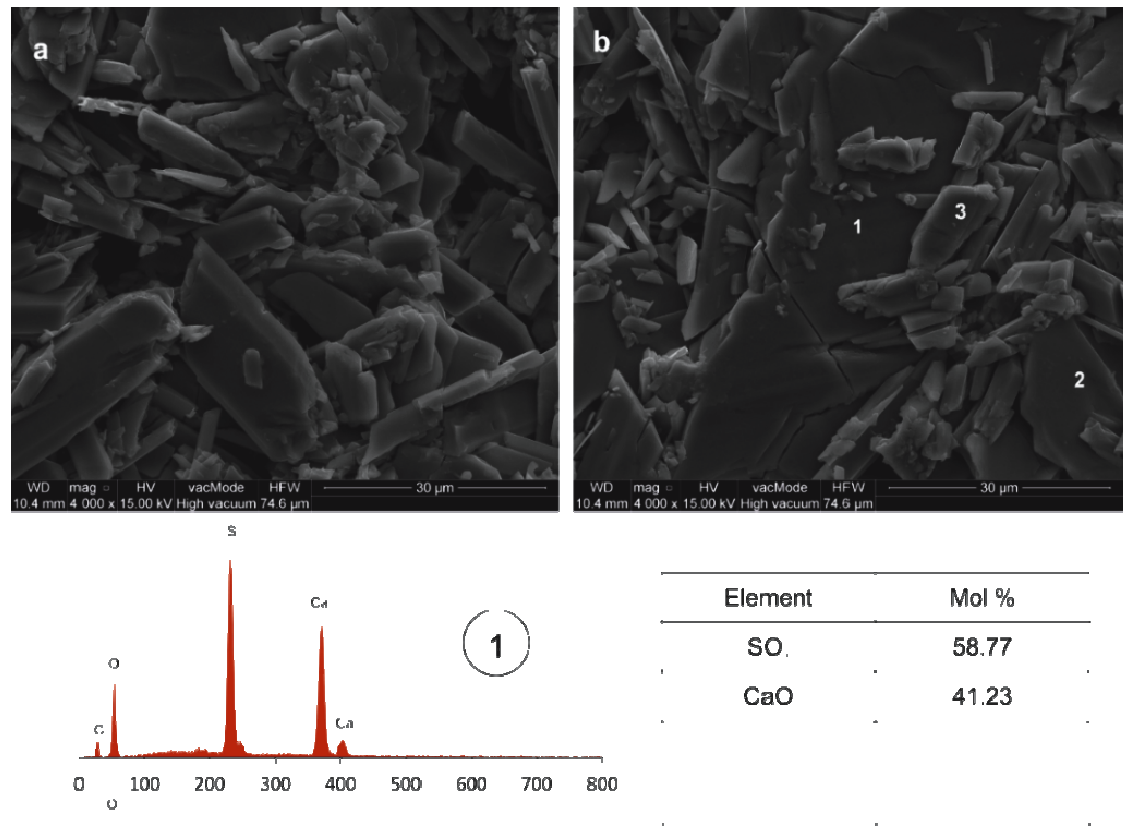

\begin{tabular}{cc}
\hline Element & Mol \% \\
\hline SO & 58.77 \\
CaO & 41.23
\end{tabular}

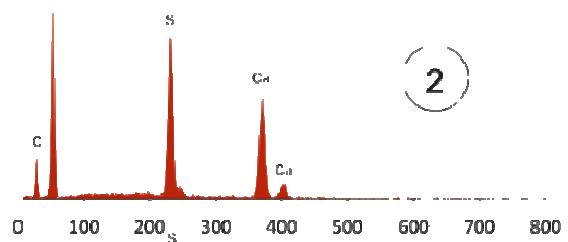

\begin{tabular}{cc} 
Element & Mol \% \\
\hline SO: & 59.62 \\
\hline $\mathrm{CaO}$ & 40.38 \\
\hline
\end{tabular}

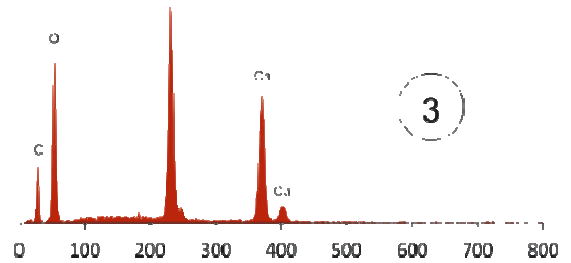

\begin{tabular}{|c|c|}
\hline Element & Mol \% \\
\hline SO & 59.85 \\
\hline $\mathrm{CaO}$ & 40.15 \\
\hline
\end{tabular}

Fig. 5. SEM-EDS images of the NF-270 membrane surface in membrane autopsy, revealing the formation of gypsum scale

\section{Studies of the membrane surface and the composition of the membrane deposits}

Based on the morphological assessment of deposits in the SEM image and the chemical composition of the deposits crystallised on the NF-270 membrane, the presence of gypsum $\left(\mathrm{CaSO}_{4}\right.$ $2 \mathrm{H}_{2} \mathrm{O}$ ) crystals was detected. In fact, multiple aggregations of the minerals are visible on microscopic images of the NF-270 membrane in place of a background of the membrane itself (Fig. 5a). In some micro-areas, these aggregations have the form of a solid layer (Fig. 6b). There are no elements other than those characteristic of gypsum $(\mathrm{Ca}, \mathrm{S}$ and $\mathrm{O})$ in spectra showing the chemical composition (Fig. 5b). In fact, during the test procedures antiscalant was not used to prevent gypsum precipitation and probably it could be needed when the water treatment process would be realised in long-term operations.

Deposits of a different character were found on the NF-DK membrane. Orange-brown compounds are present here. In microscopic images, aggregations of iron and aluminium oxide/hydroxide grains can be observed on the membrane surface (Figs. 6a-c). These aggregations build up on the membrane surface (Fig. 6). Photomicrographs of the crystallised compounds show their very fine grain sizes and irregular shapes. An elevated sulphur content was found in some micro-areas (Fig. 6b), which is most probably related to the crystallisation of iron and aluminium sulphates. No gypsum deposits were found, however.

The analysis of retention levels of calcium and sulphate ions (Tables 3 and 4) demonstrated that slightly better results were obtained using the NF-270 membrane. However, in this case the intensive concentration polarisation process could have affected the precipitation of gypsum crystals on the membrane surface. The character of the resulting secondary minerals could also have been affected by factors resulting from membrane characteristics (Table 1) and the mass transport mechanism. The differences are in the case of membrane materials, polyamide (NF-DK) and polyamide thin-film composite (NF-270), and also with respect to molecular weight cut-off. When the study results are viewed in the context of permeate flow changes over time (as shown in Figs. 3 and 4), it can be unequivocally stated that the NF-270 membrane exhibits better performance at all stages of the experiment (at pressures of $0.8,1.0$ and 1.2 MPa), but this performance tends to decrease over time. Nanofiltration using the NF-DK membrane was ca. 30\% less efficient, but the process was more stable. This fact was also reflected in the characteristics seen in the microscope images of the membranes with the result of crystal precipitation on the membrane NF-270. 

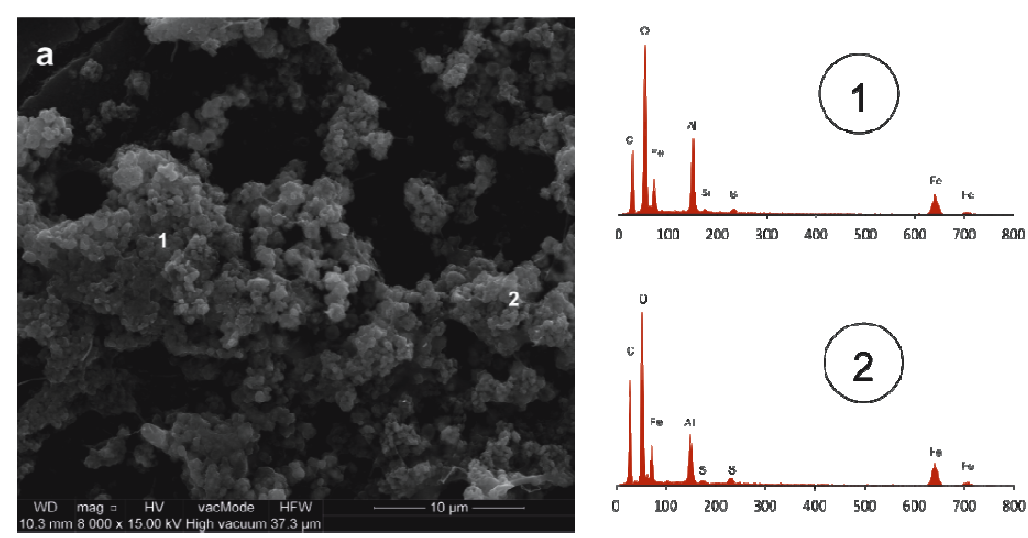

\begin{tabular}{|c|c|}
\hline Element & Mol\% \\
\hline Al. O. & 46.77 \\
\hline $\mathrm{SIO}_{\mathrm{i}}$ & 2.32 \\
\hline $\mathrm{SO}_{*}$ & 3.00 \\
\hline $\mathrm{Fe}_{\mathrm{O} . \mathrm{O}}$ & 47.91 \\
\hline
\end{tabular}

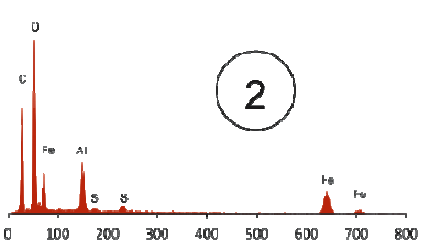

\begin{tabular}{|c|c|}
\hline Element & Mol\% \\
\hline $\mathrm{Al} ; \mathrm{O}_{;}$ & 33.35 \\
\hline $\mathrm{SiO}$ & 1.42 \\
\hline $\mathrm{SO}$ & 4.52 \\
\hline $\mathrm{Fe}_{3} \mathrm{O}_{3}$ & 60.71 \\
\hline
\end{tabular}
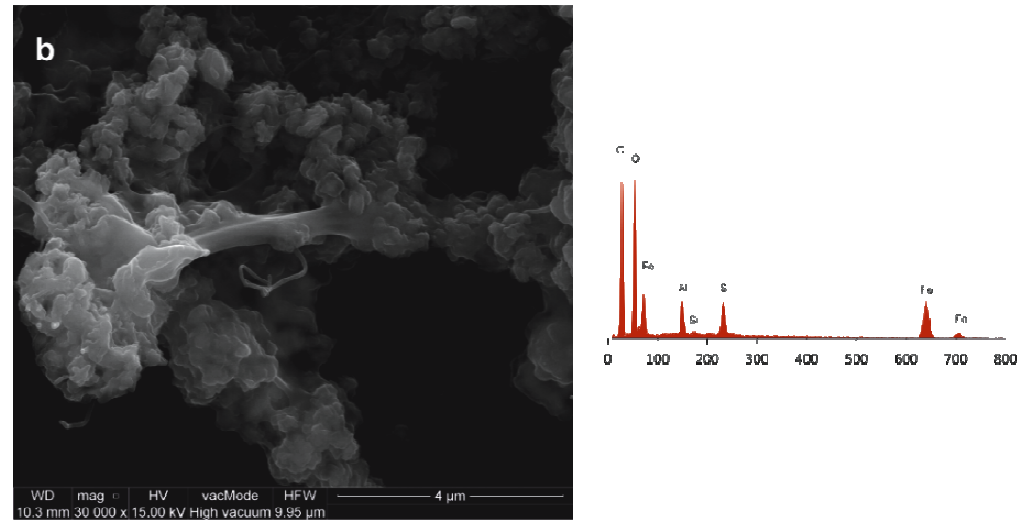

\begin{tabular}{|c|c|}
\hline Element & Mol\% \\
\hline $\mathrm{Al}, \mathrm{O}$. & 16,41 \\
\hline $\mathrm{SiO}$ & 1.97 \\
\hline $\mathrm{SO}$ & 17.64 \\
\hline $\mathrm{F} \theta, \mathrm{O}$, & 63.98 \\
\hline
\end{tabular}
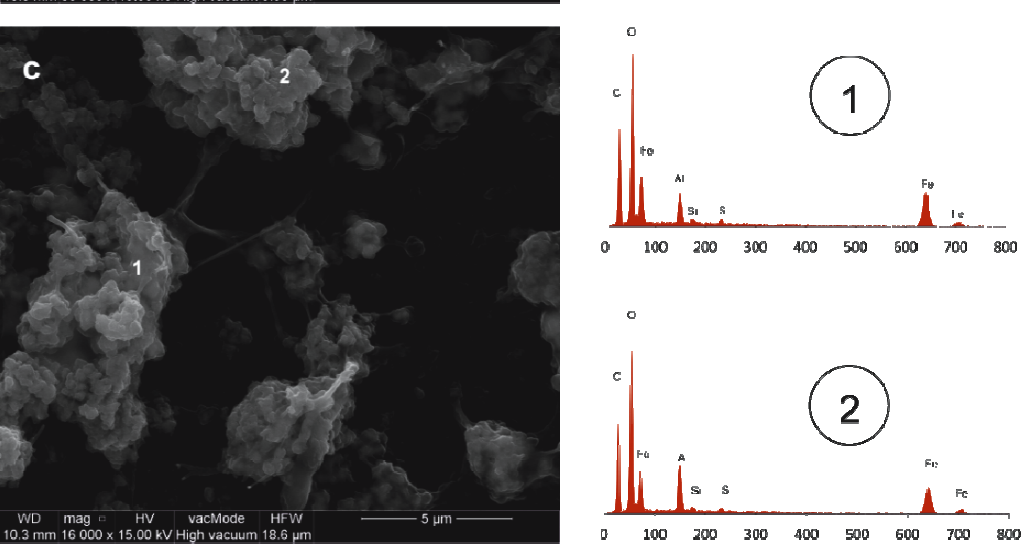

\begin{tabular}{|c|c|}
\hline Elemenl & MOl\% \\
\hline $\mathrm{Al}_{i} \mathrm{O}$ & 16.70 \\
\hline $\mathrm{SiO}$ & 2.81 \\
\hline SO & 3.40 \\
\hline $\mathrm{FeO}$ & 77.09 \\
\hline
\end{tabular}

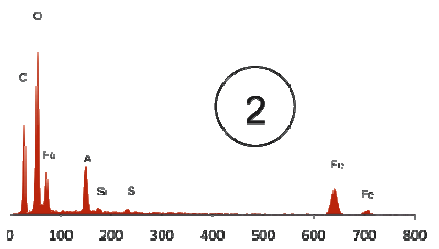

\begin{tabular}{|c|c|}
\hline Element & Mol\% \\
\hline Al: $\mathrm{O}_{2}$ & 28.87 \\
\hline $\mathrm{SIO}_{:}$ & 2.39 \\
\hline $\mathrm{SO}_{2}$ & 2.66 \\
\hline $\mathrm{Fe} \mathrm{O}_{\mathrm{O}}$ & 66.07 \\
\hline
\end{tabular}

Fig. 6. SEM-EDS images of the NF-DK membrane surface in membrane autopsy, revealing the formation of oxides/hydroxides of iron and aluminium scale

\section{Conclusions}

This study demonstrates that nanofiltration process can be used as an effective method to reduce the sulphate ions in mineral water, however carefully selection of membrane should be done before each experiment. In our tests two commercially available membranes have been used: NF-270 and NF-DK and both of them demonstrate high reduction of $\mathrm{SO}_{4}^{2-}$ ions, 79-98.7\% depends on the transmembrane pressure. Because the process of NF allows for relatively high reduction of bivalent ions, a significant reduction in calcium ion content (84-88\%) and magnesium (84-89\%) has been obtained. In fact the TDS has also been reduced in $51-64 \%$.

The studies have shown a loss of membrane efficiency with time during the NF, especially in the case of NF-270 membrane process which indicates the efficiency of, fouling and/or scaling phenomena. Based on a morphological assessment of the deposits in the SEM image and their chemical composition, the presence of gypsum $\left(\mathrm{CaSO}_{4} \cdot 2 \mathrm{H}_{2} \mathrm{O}\right)$ crystals was detected on virtually the entire surface of the NF-270 membrane. The deposits formed on the NF-DK membrane were of a completely different character as aggregations of iron and aluminium oxides/ hydroxides were found, locally with elevated sulphur content. However, no gypsum deposits were found on this latter membrane. Such significant mineralogical differences between the secondary deposits crystallising on the surface of the membranes point to the impact of several factors on these processes, including membrane characteristics, concentration polarisation, mass transport mechanisms, etc. The NF-270 membrane, which exhibited a slightly higher (ca. 30\%) permeate yield, turned out to be more susceptible to scaling which resulted in the formation of a layer that decreased its performance over time. 


\section{Acknowledgement}

This work was financed by the Polish National Centre for Research and Development, grant No 245079 (2014-2017).

\section{References}

Al-Amoudi, A., Williams, P., Mandale, S. \& Lovitt, R.W. (2007). Cleaning results of new and fouled nanofiltration membrane characterized by zeta potential and permeability, Separation and Purification Technology, 54, 2, pp. 234-240.

Burn, S., Hoang, M., Zarzo, D., Olewniak, F., Campos, E., Bolto, B. \& Barron, O. (2015). Desalination techniques - A review of the opportunities for desalination in agriculture, Desalination, 364, pp. $2-16$.

Directive 2009/54/Ec of the European Parliament and of the Council, of 18 June 2009, on the exploitation and marketing of natural mineral waters, Official Journal of the European Union, L 164/45.

Ernst, M., Bismarck, A., Springer, J. \& Jekel, M. (2000). Zeta-potential and rejection rates of a polyethersulfone nanofiltration membrane in single salt solutions, Journal of Membrane Science, 165, pp. 251-259.

Fritzmann, C., Löwenber, J., Wintgen, T. \& Melin, T. (2007). State-of-the-art of reverse osmosis desalination, Desalination, 216, pp. 1-76.
Nawrocki, J. (2010). Water treatment. Physical, chemical and biological processes, Wydawnictwo Naukowe PWN, Warszawa-Poznań 2010. (in Polish)

Nghiem, L.D. \& Hawkes, S. (2007). Effects of membrane fouling on the nanofiltration of pharmaceutically active compounds (PhACs): Mechanisms and role of membrane pore size, Separation and Purification Technology, 57, pp. 182-190.

Regulation of the Ministry of Health of 31 March 2011 concerning natural mineral waters, spring waters and table waters, (Dz. U. $\mathrm{Nr} 85$, poz. 466) Warszawa 2011. (in Polish)

Schaep, J. \& Vandecasteele, C. (2001). Evaluating the charge of nanofiltration membranes, Journal of Membrane Science, 188, pp. 129-136.

Tomaszewska, B. \& Bodzek, M. (2013a). Desalination of geothermal waters using a hybrid UF-RO process. Part II: Membrane scaling after pilot-scale tests, Desalination, 319, pp. 107-114.

Tomaszewska, B. \& Bodzek, M. (2013b). Desalination of geothermal waters using a hybrid UF-RO process. Part I: Boron. removal in pilot-scale tests, Desalination, 319, pp. 99-106.

Tomaszewska, B., Pająk, L. \& Bodzek, M. (2014). Application of a hybrid UF-RO process to geothermal water desalination. Concentrate disposal and cost analysis, Archives of Environmental Protection, 40(3), pp. 137-15.

\section{Nanofiltracyjne uzdatnianie wody mineralnej}

Streszczenie: W pracy przedstawiono wyniki badań, z wykorzystaniem wód mineralnych oraz nanofiltracji. Zastosowano komercyjną membranę nanofiltracyjną NF-270 firmy Dow Filmtec oraz membranę oznaczoną jako NF-DK firmy GE. Filtrację prowadzono dla odzysku wody wynoszącego 50\%, pod ciśnieniem transmembranowym w zakresie 0,8-2,0 MPa w układzie filtracji dead-end. Dodatkowo permeat uzyskany w nanofiltracji filtrowano przez kolumnę wypełnioną skałą wapienną o frakcji 1,0-3,0 mm, w celu poprawy składu mineralnego wody. Badana woda mineralna posiadała charakter wody siarczanowo-chlorkowo-sodowo-magnezowo-wapniowej, natomiast permeat po NF wykazywał chlorkowo-sodowo-potasowy typ hydrogeochemiczny. W wyniku uzdatniania wody w procesie NF, uzyskano wysoką redukcję jonów $\mathrm{SO}_{4}-96-98 \%$, natomiast TDS zostało obniżone o ok. 51-64\%. Ponieważ proces nanofiltracji pozwala na stosunkowo wysoką redukcję jonów dwuwartościowych, uzyskano również znaczące obniżenie zawartości jonów wapnia (84-88\%) i magnezu (84-89\%). Jony jednowartościowe obniżone zostały w mniejszym stopniu, tj. sód (46\%), a wodorowęglany (49-51\%). Filtracja permeatu, po membranie DK-NF, na złożu $\mathrm{CaCO}_{3}$, doprowadziła do korekty typu hydrogeochemicznego permeatu, z chlorkowo-sodowo-potasowego na chlorkowo-wodorowęglanowo-sodowy. Na podstawie oceny morfologicznej osadów w obrazach SEM i ich składu chemicznego, na powierzchni membrany NF-270 stwierdzono obecność kryształów gipsu. Osady utworzone na powierzchni membrany NFDK miały zupełnie inny charakter. Stwierdzono skupiska tlenków/wodorotlenków żelaza i glinu. Nanofiltracja jest odpowiednią metodą pozwalającą na modyfikację smakową wody mineralnej. 